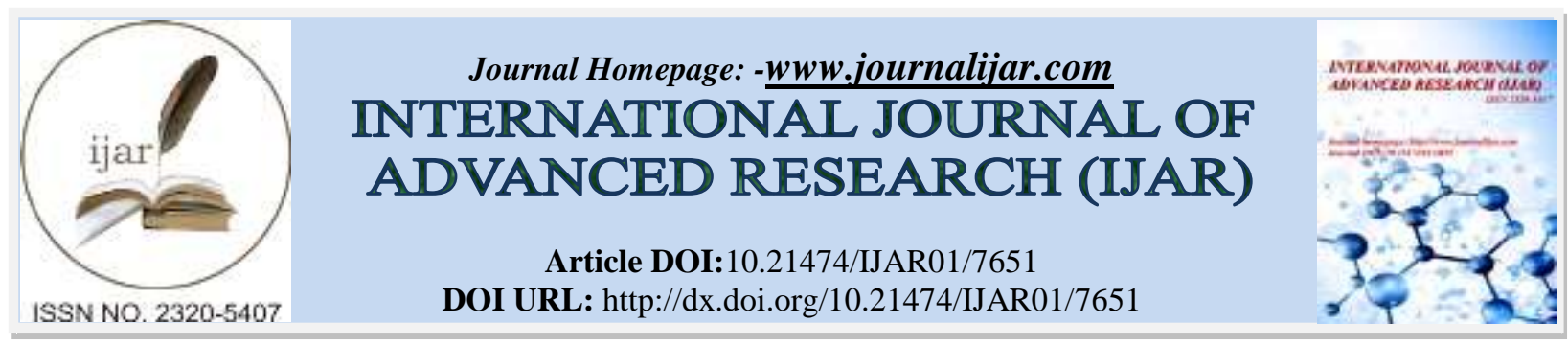

RESEARCH ARTICLE

\title{
STRATEGIC IMPERATIVES OF ACT EAST POLICY OF INDIA.
}

Ashwini Sharma And Dr Navin Varma.

Dept of Defence Studies, Meerut College, Meerut.

\section{Manuscript Info}

Manuscript History

Received: 03 July 2018

Final Accepted: 05 August 2018

Published: September 2018

Keywords:-

ASEAN, Act East Policy, Look East

Policy, Sea Lines of Communication.

\begin{abstract}
India and China have multifaceted interests in ASEAN. Both countries work towards collaboration and co-operation. Strategic interests of such major powers cannot be always complementing, but competing. India's Act East Policy (AEP), which has major stakes in the ASEAN, thus ought to compete with the Chinese interests in the region while charting its plan of action. Economic and security concerns of both countries assume greater primacy and drive the significance of their interests in the competition. It is therefore imperative to study as to how India and China are disposed off towards East Asian Nations and in turn, how they see their role and influence in the region. This article discusses the strategic imperatives of India's AEP.
\end{abstract}

Copy Right, IJAR, 2018,. All rights reserved.

\section{Introduction:-}

Post Cold War developments at the domestic, regional and global level presented ample opportunities for India and South-East Asia to develop close multi-faceted ties with huge potential for benefits for both sides. To this effect, India's launch of Look East Policy (LEP), which later evolved as Act East Policy(AEP) had its focus primarily on Association of South East Asian Nations (ASEAN). Accordingly, ASEAN had since then acquired priority in India's foreign policy agenda and continues to receive sustained focus. The strategic dimension of AEP has multiple facets of which security and economy assume prominence that are deliberated in this paper.

\section{Strategic Imperatives}

The strategic underpinning and key drivers that have propelled India to pursue 'Look East' policy that eventually graduated as AEP are essential as a prelude and discussed below.The LEP was evolved with an attempt to rediscover Asia, restore and strengthen its past historical, cultural and economic relations with the region of Southeast Asia that had for many decades been neglected. The chief drivers of the LEP are its large and growing population and the need to sustain economic development in order to keep up with the population, the need for natural resources and combating the potential regional or global security threats. India's current foreign policy especially as entrenched in the LEP is driven primarily by its desire to maintain, sustain or increase its security. The necessity to address the challenges is brought about by the changed world order. The policy evolved out of the need to developing stable political, economic and strategic relations in the changing global scenario and the need to forge stronger ties with the countries of Southeast Asia. At the political level, through the LEP, India seeks political integration with the Southeast Asian countries and then to East Asia. The common security concerns relating to transnational crimes and maritime security have brought India to closely engaging with the countries of Southeast Asia. India's strategic interests demand a close defence and security partnership with the countries of the region, both in facing external threats and in meeting its aspirations to be a global power. By closely engaging strategically with ASEAN, India seeks to hedge its vulnerability of eastern sectors. China's expanding footprint in Southeast Asia and in particular in 
Myanmar, is a case of concern for India. Besides, India seeks to prevent the insurgent groups operating in Northeast region of our country from gaining shelter and support from the Myanmar.

\section{Globalisation and Liberalisation}

The process of globalization and liberalization had its own consequences for India's AEP and its strategic engagement with Southeast Asia. Post Cold War, liberalization of the Indian economy, and the launch of LEP, have compelled India and ASEAN to strengthen the partnership and play a more proactive role in regional and world affairs. It is also evident that the economic complementariness and the socio-cultural affiliation with the ASEAN offered an opportunity for deeper engagement in the initial phases. With gaining political understanding India has not only proved itself to be a reliable partner but also as a co-investor of political and economic stability in South East Asia. The imperative for stronger ties stems from the political and security environment, globalization, technological changes, and institutional foundations, is well evident in the AEP framework.

\section{Geo-Strategic Interests}

Geo-strategic interests of India and China in South East Asian region, are essential strategic dimension and are discussed below. The substance of any strategic relationship depends on the closeness and depth of interactions, the convergence of interests and the devotion of the countries to accommodate each other's concerns. It is driven by converging long-term political, economic and strategic interests, aspirations and concerns, underpinned by a common commitment to democracy, open society, human rights, rule of law and free market economy. India and ASEAN economies are among the most successful in terms of economic growth and development. Their cooperation would be crucial for their economic progress and this would reflect in their standing among the countries of the world. India's partnership with ASEAN is well within these tenets and has the potential to not only serve the long-term interests of these countries, but also enhance all-round cooperation to address regional and global challenges. India and ASEAN can help each other in fulfillment of common objectives by enhancing mutual cooperation in the political, economic and strategic sphere. Following are major geo-strategic interests of AEP :-

1. Security of the Sea Lanes of Communications (SLOCs)

2. Combating Terrorism and its Related Activities

3. Supporting Peace, Security and Stability in the Region

\section{Convergence of Strategic and Economic Interests}

It is evident in the way India conducted its business with ASEAN countries in last three decades,that converging economic and strategic interests are bringing India and Southeast Asia together on stronger footing.India and ASEAN economies are among the most successful in terms of economic growth and development. Their cooperation would be crucial for their economic progress and this would reflect in their standing among the countries of the world. India and ASEAN can help each other in the fulfillment of common objective by enhancing mutual cooperation in the political, economic and strategic sphere. They have in the recent past developed close convergence in security prospects and have vital stakes in peace, security and stability in the region, including the fight against terrorism, piracy, arms and drug trafficking and the security of the SLOC in Indian Ocean for smooth flow of raw materials, merchandise and energy supplies. Establishment of ASEAN India Network of Think Tank (AINTT) in New Delhi can be seen as one of the major strategic partnership forged between India and ASEAN. Joint fight against terrorism and security of Sea Lanes of Communications, are another set of major considerations for strategic partnership between India and ASEAN. However, this convergence should not be conceived or directed against the rise of China.

Economic and trade cooperation is an important aspect of the growing multi-dimensional partnership between India and ASEAN. The potential of economic engagement can be reflected from the fact that both the economies of ASEAN and India together account for US\$2,809.58 million. India is one of the largest economies of the Asian region and the ASEAN countries together have become both prominent and influential owing to their increased importance in trade and commerce.

\section{Influence of China}

The possible measures, India can and should adopt to contain the influence of China over ASEAN countries to enhance the effectiveness of its AEP, are outlined below. The role and influence of China over ASEAN is well established. Much against India's wishes, the economic ties between China and ASEAN are well above that of India. In addition, the China's soft power initiatives in the region are substantial and growing. However, India can extend its cultural ties and economic co-operation slowly and steadily in the region. Exploiting the cultural and 
traditional ties of North Easter Region(NER) with some of its needy neighbor, are well within its capabilities. Military cooperation and joint exercises in Indian Ocean and Bay of Bengal, to assert itself as superior maritime power continues to be its major option. India's power projection and strong partnerships in the region as a big brother, who understands and shares the interests of the region, helps fostering better ties to contain China. Development of NER as a major trading route and economic development in the region will eventually contain insurgency and bring in political stability, which is one of the major concerns of India.

\section{Conclusion:-}

International relations are invariably based on mutual trust and mutual benefits. Cooperative endeavours based on mutual trust and confidence will lead to enduring development and proper accomplishment of the Policy.The very nature of LEP is based on this strategic underpinning. India's growing geo-strategic interests in East Asia and specially ASEAN, in the back drop of Chinese influence in the region, defines the strategic dimensions. India's globalization in the last two decades has resulted in a grand strategic shift in favour of India. While the Chinese influence is predominant in the region, India has done fairly well to engage the East Asian community and stay engaged. The ascendancy of India in regional forums of East and Southeast Asia, is major evidence of India's growing ties and reciprocity it enjoys. Convergence of economic and strategic interests of India as well as China and ASEAN, coupled with policy shift and multitude of Free Trade Agreements, help India foster better with ASEAN countries for common benefits.

\section{References:-}

1. BaladasGhosal(2013), “China's Perception of 'India's LEP' and Its Implications”, IDSA Monograph Series.

2. LalitMansingh(2012), "The LEP and Its Implications for Eastern India", in Amar Nath Ram (ed.), Two Decades of India's LEP : Partnership for Peace, Progress and Prosperity, Manohar Publications, New Delhi.

3. S. D. Muni(2012), “LEP : Beyond Myths”, in Amar Nath Ram (ed.), Two Decades of India's LEP : Partnership for Peace, Progress and Prosperity, Manohar Publications, New Delhi.

4. ShankaranNambiar(2011), “India's Engagement with ASEAN: Beyond Trade in Goods”, ISAS Working Paper.

5. SurjitMansingh(2005), "Indo-US Relations: A Closer Relationship?", Economic and Political Weekly,Mumbai.

6. SuryakanthiTripathi(2012), "Impress the East, Know the East, Engage the East: India's Relations with ASEAN", Manohar Publications, New Delhi.

7. VikramNehru(2013), "Six Reasons for India to Look and Act East", accessed at http://carnegieendowment.org/ 